\title{
LOS JUDIOS DEL REINO DE VALENCIA DURANTE EL SIGLO XV
}

\author{
José Hinojosa Montalvo \\ Universidad de Alicante
}

La Historia del judaísmo valenciano se inscribe entre una fecha de partida y otra de llegada clara: los pogroms de 1391 y la expulsión de 1492 , sin que haya especiales fisuras intermedias. En este siglo hubo importantes transformaciones, comenzando por la misma demografia: se produjo un notable descenso del número de judíos con relación al período anterior a 1391, a raíz de la conversión, muerte o emigración de muchos antiguos hebreos, hasta el punto que en el momento de embarcarse en 1492 rumbo al exilio apenas superaban el millar de personas, lo que suponía un porcentaje insignificante en el total poblacional del reino.

Hubo también una redistribución geográfica de las aljamas; y la regularidad de los siglos XIII y XIV en cuanto a la distribución espacial. particularmente en las villas de realengo de la costa, dejó paso a una concentración en la zona central del reino, entre Castellón de la Plana y Játiva, con su epicentro en Morvedre (Sagunto). Desaparecieron las aljamas de la zona Norte, y en las del Sur apenas subsistieron alguhos hebreos en Orihuela.

Se produjo un cambio de jerarquización en las aljamas al desaparecer la judería de Valencia y pasar el papel rector del judaísmo valenciano de esta aljama a la de Morvedre, la más poblada y dinámica.

La realidad es que el judaísmo valenciano quedó herido de muerte a partir de los pogroms de 1391, que destruyó numerosas juderías y de-

"Texto de la conferencia publicada en Alicante en mayo de 1983 con motivo del ciclo que sobre La sociedad peninsular en la Edad Media organizaron el Departamento de Historia Medieval de la Universidad de Alicante y la Caja de Ahorros Provincial. 
sorganizó en alto grado la sociedad hebrea, sobre todo por las conversiones.

La política de la monarquía de Juan I fue la de favorecer la reconstrucción de las aljamas, ya que ello redundaba en beneficio de su propio patrimonio, pero estos intentos no siempre culminaron satisfactoriamente, siendo en las pequeñas localidades donde la reconstrucción fue más fácil. Pasada la situación de peligro los judíos refugiados en el castillo de Morvedre o en tierras de señorío fueron regresando a sus antiguos hogares y lentamente se fueron reactivando las juderías de Burriana, Castellón, Villarreal o Játiva, tarea que finalizaría en la segunda década del siglo XV. Al mismo tiempo, los reyes apoyaron a los judios con todo tipo de privilegios, en particular perdones, generales o particulares, salvoconductos, etc.

Eso sí, trataron de combatir, con desigual éxito, la fuga de conversos de sus reinos, que intentaban reconstruir sus vidas en la fe de sus antepasados huyendo clandestinamente al norte de África o a Granada. Juan I tuvo que compaginar la postura religiosa de evitar la apostasía con la política de no perder unos vasallos, lo que tendría graves repercusiones económicas. De ahí los perdones otorgados a los que regresaban (1).

La situación se endureció con Martín I, que trató de resolver el problema creando fuertes barreras entre los judíos y conversos. Era el resultado del choque entre la tendencia realista y humanitaria, tolerante hacia los judios, con la de aquellos que se inclinaban por el extremismo religioso (2). En este caso se hallaban las autoridades de la ciudad de Valencia, que continuamente exigian del monarca medidas restrictivas contra los judios. Tal presión se plasmó en una serie de medidas antijudias en las Cortes de Valencia de 1403, que luego analizaremos, pero que en síntesis restringían la permanencia temporal y espacial de los judios en Valencia, prohibiendo su residencia en las parroquias de Santo Tomás, San Andrés y San Esteban -antigua judería-, y cualquier contacto con los conversos. También se regulaba su estancia por razones comerciales, aspectos clave de su vida cotidiana - pan o carnes- o sus festividades. Las medidas tuvieron vigor durante toda la centuria.

La entronización de la dinastía Trastámara tras el Compromiso de

(1) ARCHIVO DE LA CORONA DE ARAGÓN (A.C.A.). Cancillería real, reg. 1877, fol. 89 v. -90 r.; reg. 1881 , fol. 40 r. -41 r.; reg. 1880 , fol. 164 r. -165 r.; reg. 1881 , fol. 86 r

(2) BAER, Yitzhak, Historia de los judios de la España cristiana, Madrid, 1981, pág. 407. 
Caspe y la confluencia de tres personalidades, como la de Benedicto XIII, San Vicente Ferrer y Fernando I, motivaron un endurecimiento de la actitud contra los hebreos, plasmada en las predicaciones del fraile dominico valenciano y las subsiguientes conversiones masivas, avivadas por el antijudaísmo popular. En Valencia ello se plasmó en la prohibición a los conversos de residir en el antiguo recinto judío y su dispersión urbana. La Disputa de Tortosa parece que no tuvo repercusiones entre los judíos valencianos.

La política judía de Alfonso $V$ fue radicalmente distinta de su predecesor, anulando en 1419 las leyes restrictivas anteriores y la bula de Benedicto XIII (3). Las medidas proteccionistas de la corona tuvieron una repercusión inmediata y las aljamas valencianas comenzaron en la década de los veinte su despegue, estabilizándose su status jurídico y llevando en lo sucesivo una vida tranquila. No obstante, los judios dejaron de tener influencia alguna en la vida política de los reinos de la Corona de Aragón.

Desde los años setenta, sin embargo, se detecta una nueva crisis, un empobrecimiento de las comunidades judías, particularmente en la Plana castellonense, donde Villarreal y Burriana entran en un proceso de decadencia irreversible en beneficio de la cercana Morvedre, a donde emigraron estos judíos.

De hecho, en 1492, las únicas comunidades judías destacadas eran las de Morvedre y Játiva y los judíos ya no tenían la importancia económico-social anterior a 1391. Pero veamos cómo se articulaba la sociedad judia y qué factores le servían como elemento de aglutinación o segregación.

\section{I.-SOCIEDAD Y SEGREGACION EN LOS JUDIOS VALENCIANOS}

\section{Los asaltos a las juderías en 1391}

El suceso es relativamente bien conocido, ya que su magnitud e impacto posterior llamaron pronto la atención de los historiadores, centrándose en el reino de Valencia en la destrucción de la judería de la

(3) JIMÉNEZ JIMÉNEZ, M. Rosa, La politica judaizante de Alfonso $V$ a la luz de las concesiones otorgadas en 1419 a la aljama de Murviedro. IV Congreso de Historia de la Corona de Aragón, Palma de Mallorca, 1951, pág. 251-262. ARCHIVO DEL REINO DE VALENCIA (A.R.V.), Real, 630, fol. 235 r-sig. 
capital. Recientes estudios han ampliado nuestros conocimientos sobre otras juderias (4).

La destrucción y robo de la judería de VALENCIA tuvo profundas motivaciones. Hoy, las explicaciones religiosas ya no satisfacen y se hace hincapié en otros factores de carácter social, económico o polftico. Kriegel ha recordado el vacio de poder existente en aquellos momentos en Castilla (5) o las dificultades en Cataluña. Ya en 1886 Danvila resaltaba el rencor latente en la sociedad cristiana hacia los judios por sus exigencias prestamistas (6). Para Vidal Beltrán fue la ocasión para dirigir contra una minoría rica el rencor basado en razones económicas y fomentado por una propaganda de tipo social y religioso (7). Resentimiento acrecentado por la expansión de los judíos fuera del recinto de la judería.

Las noticias de los asaltos y saqueos en Castilla llegaron rápidamente a Valencia y el temor cundió entre los judíos, a pesar de las medidas de protección adoptadas por los jurados. Ello no impidió que el domingo 9 de julio de 1391 estallara el motín. No vamos a detenernos en detalles, ya que ha sido minuciosamente descrito en otras ocasiones. Señalar que en el asalto participaron gentes de toda condición social, desde artesanos a hombres de linaje, frailes y religiosos mendicantes, y no vagabundos o gentes humildes y extranjeros, a los que se escogía siempre como chivos expiatorios.

Las autoridades trataron de evitar que saliera de la ciudad lo robado y de dar al menos una apariencia de justicia, sin resultado positivo. Se ordenó devolver lo robado y se nombraron comisiones para su inventario, y aunque se devolvieron bienes, la parte más importante no se recuperó nunca. Por testimonios conservados de algún judío sabemos que cuadrillas de individuos, en algún caso capitaneadas por gente de alcurnia, robaron la documentación comprometedora de deudas, lo que revela el matiz económico de la agresión (8).

(4) Entre otros, pueden verse, DANVILA, Francisco, El robo de la juderia de Valencia en 1391. Boletin de la Real Academia de la Historia, 8 (1886), pág. 370-371. VIDAL BELTRÁN, Eliseo, Valencia en la época de Juan I, Valencia, 1974, pág. 54-59. RIERA SANS, Jaume, Los tumultos contra las juderias de la Corona de Aragón en 1391. Cuadernos de Historia, 8 (1877), pág. 213-225.

(5) KRIEGEL, Maurice, Les juifs à la fin du Moyen Age dans l'Europe Mediterraneene, París, 1979, pág. 206.

(6) DANVILA, F., op. cit., pág. 370-371.

(7) VIDAL BELTRÁN, E., op. cit., pág. 53.

(8) DANVILA, F., op. cit., pág. 390. 
Desde un punto de vista criminal no se llegó a ninguna conclusión positiva. Había muchas partes implicadas para que ello fuera posible. Las autoridades municipales se vieron desbordadas por la revuelta y fueron incapaces de oponerse a ella. El infante don Martín, a la sazón residente en Valencia, lugarteniente general del reino, tampoco estuvo a la altura que requerían los sucesos. Buenas intenciones de palabra, pero nada más. $Y$ ello se lo reprochó su hermano Juan I en duras cartas. Claro, que el rey, con su carácter indolente, no demostró mucha más energía y todo se quedó en cartas dando instrucciones o agradecimientos por proteger a los judios.

Se detuvieron unos diez notables y 70 u 80 del pueblo, acusados de ser los más culpables. Pero la ciudad tuvo que enfrentarse con una serie de factores que fueron retrasando el proceso y haciéndole perder efectividad. Fueron: las acusaciones en contra de la ciudad promovidas por los mismos acusados, que predisponen al rey contra los jurados; la necesidad de aquietar a la población mudéjar ante el peligro de una ayuda granadina; la cuestión de competencia planteada por el mismo gobernador; la despreocupación del infante don Martín y la negligencia del rey. Al final, como en otras poblaciones, se llegará a un acuerdo económico en 1392 y los cinco más culpables serían ahorcados, y otros 20 expulsados de los territorios de la Corona.

Las consecuencias del asalto fueron gravísimas para el judaísmo valenciano: muerte o conversión forzada de sus miembros, robo de viviendas y propiedades. El número de judíos muertos, según una carta particular, fue de 230 y de $10 \circ 12$ cristianos (9). La conversión fue masiva en todas las juderías, incluyendo personajes de alcurnia como el célebre Ishaq bar Sese Perfet (Jaime de Valencia), que luego volvió al judaísmo en el norte de África (10); o don Samuel Abravalla (Alfonso Fernández de Vilanova). Muchos fueron apadrinados por personajes de gran relieve social, de los que tomaron su nombre y apellido. Pero el problema converso queda fuera de este estudio.

De los sucesos del verano de 1391 en MORELLA no han quedado testimonios, si bien Grau Monserrat considera que se produjo la destrucción de la judería y la conversión de sus miembros (11). En SAN

(9) VIDAL BELTRAN, E., op. cit., pág. 57. Archivo de los Condes de Faura. Correspondencias, $n .^{\circ}$ 13. La cita procede de DANVILA, F., op. cit., pág. 392.

(10) A.C.A. Cancilleria real. Regi 2.093, fol. 163 r.- 164 r.

(11) GRAU MONSERRAT, Manuel, La juderia de Morella (siglos XIII-XIV). Sefarad, XXII (1962), pág. 69-81- XXIV (1962), pág. 298-321. En concreto, pág. 304. 
MATEO parece que no hubo violencias físicas contra los judíos, aunque sí intentos de injuriarlos de palabra y hecho (12).

La aljama de MORVEDRE fue una excepción en aquellos días aciagos, ya que es la única que se libró de las muertes y saqueos, gracias a la eficaz protección dispensada por las autoridades a los judíos, aunque estuvo la judería a punto de ser atacada por gentes de Valencia, Morvedre y su castillo fue el refugio para aquellos que trataban de mantener su fe. El rey y las autoridades del reino felicitan en diversas ocasiones a las autoridades de la villa por su custodia a los hebreos. Con todo, éstos, refugiados en el castillo, atravesaron momentos difíciles al ver sus actividades y su economía paralizada, si bien a partir de 1392 la aljama saguntina comienza a recuperar su ritmo normal.

El saqueo de la aljama de BURRIANA se conoce bien gracias a los trabajos de Piles Ros (13), participando en el mismo los vecinos de la villa y los de Villarreal, por lo que sus jurados debieron abonar al monarca 7.000 sueldos como multa, cantidad que ascendió a 13.000 sueldos para los de Burriana. El asalto, que produjo un cuantioso botín, rebasó el marco físico de la villa y se convirtió en revuelta popular, posiblemente hacia las alquerías de mudéjares de los alrededores. Como señala Valdeón, "lo que en principio era sólo un enfrentamiento basado en motivaciones religiosas se transformaba en un episodio más de la conflictividad social" (14).

En VILLARREAL, Doñate Sebastiá opina que, at igual que en la vecina CASTELLON, aquí tampoco los judíos fueron molestados (15).

Las escasas noticias sobre la destrucción de la judería de ALCIRA fueron recogidas por Chabas y luego por Piles Ros, y proceden fundamentalmente del perdón real concedido el 16 de enero de 1393, año y medio después del suceso, que fue a mediodía del lunes 10 de julio. La judería desapareció y sus moradores convertidos al cristianismo. El perdón real a la villa excluía a 32 particulares — que también fueron perdonados en marzo de 1393 - Juan I cobró 800 florines (16). Los intentos por reconstruir la judería fracasaron.

(12) A.C.A. Cancillería real. Reg. 1.878 , fol. 74 v. -75 r.

(13) PILES ROS, Leopoldo, La judería de Burriana. Sefarad, XII (1952), pág. 105-124.

(14) VALDEON BARUQUE, Julio, Los conflictos sociales en el reino de Castilla en los siglos XIV y XV, Madrid, 1975, pág. 35.

(15) DOÑATE SEBASTIÁ, J. Maria, y MAGDALENA NOM DE DEU, José Ramón, Las juderias de la Plana, Castellón, Villarreal y Burriana, en prensa.

(16) PILES ROS, L., La juderia de Alcira (notas para su estudio). Setarad, XX (1960), págs. 363-376. A.C.A. Cancillería real. Reg. 1.905, fol. 19 r. y reg. 1.903, fol. 228 r. 
El asalto de la judería de JATIVA era desconocido hasta ahora en su proceso. Las noticias de ló sucedido en Valencia llegaron la mañana del 10 de julio, produciendo una fuerte tensión entre las gentes, que las autoridades trataron de contrarrestar. Sin embargo, la noticia del asalto y conversión de los judíos de Alcira encrespó los ánimos y al anochecer la judería de Játiva fue invadida, robada y dispersada. Por fortuna, sólo murió un judío loco, que fue encontrado encadenado, ya que el resto, a consejo de los jurados, se refugió en el castillo. Las gentes congregadas en la ciudad sitiaron a los judíos para forzarles a convertirse por hambre. $Y$ así sucedió.

El justicia criminal apresó a unos 100 individuos, y como siempre, se echó la culpa a los forasteros, pero al final Juan I — dado su carácter fronterizo y la huida masiva de gentes de la ciudad por temor a represalias de la justicia—, a principios de 1393 condenaba estos delitos por dinero.

La vorágine de julio de 1391 hizo que desaparecieran las juderías de ALICANTE y ORIHUELA, villa ésta en que, a pesar de la protección de algunas autoridades y el patriciado local, no se pudo impedir la extinción temporal de la aljama (18). Parece que en Orihuela no hubo violencias físicas contra los judíos y para delimitar responsabilidades en la Gobernación de Orihuela se enviaron como comisionados reales a Francisco Desplugues y Antonio de Alagón, que también ejercieron dicha misión en otras juderías del reino. Pero el episodio es mal conocido y lo único claro es la conversión masiva de sus miembros.

\section{Aspectos demográficos}

El conocimiento cuantitativo de la población hebrea en el reino de Valencia durante el siglo XV tropieza con el problema básico de la falta de fuentes específicamente demográficas; tan sólo algunos testimonios indirectos.

En el caso de la ciudad de Valencia, tras los sucesos de 1391, todavía debieron quedar en la urbe unos 200 judíos, que vivirían mezclados con los conversos, con gran rechazo de las gentes y peligro para sus personas, por lo que se gestionó su traslado a un lugar más seguro,

(17) VENTURA, Agustí, Possible localització de la jueria o call de Xàtiva, Xativa, fira d'agost, 1977, pág. 35. A.C.A. Cancillería real. Reg. 1.904, fol. 148 r.-151 r.

(18) TORRES FONTES, Juan, Los judios murcianos a fines del siglo XIV y comienzos del XV. Miscelánea Medieval Murgetana, VIII (1981), pág. 55-118. 
escogiéndose el castillo de Morvedre. Quizá pasaran más tarde a engrosar la aljama saguntina (19).

Aunque no volvió a haber aljama en Valencia, años después encontramos algunos judíos residiendo en la capital, aunque en un estado de pobreza y hostilizados por las gentes. Su número era de 30 y se les impuso la vejatoria obligación de alimentar a los leones que el monarca tenía en su Real (20).

De la aljama de Morvedre sabemos que era la que contribuía con una pecha mayor y con unos impuestos más elevados. Su población disminuyó en 1422 a raíz de la peste, prolongándose quizá el bache demográfico hasta 1438 . En estas fechas solicitaban moratorias al rey en el pago de sus impuestos.

La recuperación vino - al margen del crecimiento vegetativo- de la inmigración de otras aljamas, en particular de la Plana de Castellón. Los únicos datos concretos son del momento de la expulsión, en que sabemos que había en la villa cien o más casas de judíos, que corresponderían a los 700 judíos saguntinos embarcados, un tercio de la población total de Morvedre en 1492.

Y mientras Morvedre aumentaba su censo judío, la villa de Burriana se quedaba prácticamente sin ellos. Durante gran parte del siglo tuvo una comunidad hebrea muy activa, pero sin que sepamos las causas en 1486 la judería cayó en destrucción, la sinagoga cerró sus puertas y los objetos de culto tuvieron que ser salvados de la rapiña de las autoridades locales, colocándolos bajo la salvaguarda de los judíos saguntinos, en espera del futuro renacer de la aljama, que nunca llegó (21).

Para Villarreal, Doñate Sebastiá y Magdalena Nom de Deu han dado la cifra de unos 50 judíos, como máximo, en este siglo (22).

La demografía de Castellón de la Plana ha sido calculada por Magdalena Nom de Deu utilizando los Libres de Values de Peytes. Frente al casi centenar de vecinos en vísperas de 1391, contrasta la baja de 1433 , con sólo 11, debido a que por entonces la judería de Castellón estaba en proceso de recuperación, amén de la peste. Los años siguientes fueron de recuperación. En 1473 habia 12 casas judías en la villa, en la parroquia de San Pedro (23).

(19) A.M.V. Lletres misives, g3-5, fol. 44 r.

(20) A.R.V. Maestre racional, 41 , fol. $118 \mathrm{r}$.-v.

(21) A.R.V. Bailia, 1158, fol. 213 v.

(22) DOÑATE SEBASTIÁ, José Maria, y MAGDALENA NOM DE DEU, J. R., Las aljamas judias de la Plana, Castellón, Villarreal y Burriana, en prensa.

(23) MAGDALENA NOM DE DEU, J. R., La aljama de judios de Castellón de la Plana en la 
En líneas generales, vemos, pues, una crisis en los años veinte y treinta, seguida de una rápida recuperación y crecimiento en los treinta años siguientes, para hundirse, salvo Morvedre, a fines de siglo. De las otras juderías no hay ningún dato.

Acerca de los MOVIMIENTOS DE POBLACION, la historia de los judíos valencianos en este siglo se encuadra entre dos grandes migraciones, una parcial, la de 1391, ya que no afectó a todas las juderías, y otra, definitiva, la de 1492. El caos que se produjo en 1391 obligó a emigrar, de grado o fuerza, a muchos judíos, a aquellos lugares que les ofrecían seguridad. Tal fue el caso de Morvedre, auténtica tabla de salvación para muchos.

Al margen de estos hechos extraordinarios, el que emigraba a otra judería lo hacía buscando mejorar su situación social y económica. No es frecuente la presencia de judios foráneos residiendo en el reino, salvo por razones mercantiles. Lo habitual es que las migraciones corran a cargo de los propios hebreos valencianos, contribuyendo de este modo a repoblar juderías como Castellón o Játiva.

Las juderías que registraron un mayor trasiego de gentes fueron las de Morvedre y las de la Plana, en razón de vínculos comerciales y familiares. Para los desplazamientos fuera del reino, los judíos debían de presentarse ante la corte de la Bailía, declarar ante el baile general el tiempo de permanencia y abonar los derechos correspondientes.

El traslado de domicilio a una nueva localidad llevaba implícitos una serie de trámites legales, siendo el más importante el del avecindamiento, que iba precedido del correspondiente desavecindamiento de la anterior residencia y la cancelación de las deudas tributarias pendientes, tema éste que originaba frecuentes rencillas y reclamaciones entre aljamas vecinas.

Muchas veces resulta difícil deslindar lo permanente de lo temporal en estas migraciones. Como criterio seguro para calificar una emigración de permanente estaría el avecindamiento, pudiendo calificarse el resto como desplazamientos temporales, de duración irregular, desde unos días a varios años. Razones económicas o familiares impulsaban a estos desplazamientos.

La estancia de judíos forasteros era autorizada por el baile general, y allí donde hubiera judería residirían con sus correligionarios. En Va-

Baja Edad Media, Castellón de la Plana, 1978. TRAVER TOMÁS, Vicente, Antigüedades do Castellón de la Plana, Castellón, 1959. 
lencia se les prohibió estar en casas de conversos y en las parroquias que abarcaba el antiguo recinto de la judería, debiendo albergarse en hostales o en el burdel. El plazo de residencia era entre varios meses y un año, tiempo necesario para que realizaran sus negocios.

La estancia de estos judíos venía garantizada por el baile con la concesión de guiajes o salvoconductos.

\section{La aljama como eje de la organización interna}

Las comunidades judías se organizaron para su funcionamiento en aljamas o asambleas allí donde la población hebrea tenía una cierta entidad numérica (24). Durante el siglo XV las aljamas del reino fueron las de Castellón de la Plana, Villarreal, Burriana, Morvedre y Játiva. Desde 1391 habian desaparecido las de Morella, Valencia, Alcira, Gandía, Orihuela, Elche y Alicante, quedando en estas localidades algún judío aislado.

La estructura interna de estas aljamas era muy parecida a las restantes de la Corona de Aragón. Los adelantados (adelantats) eran el equivalente de los jurados en los concejos cristianos y sobre ellos recaían las principales tareas de la aljama; los consejeros (consellers) formaban el cuerpo deliberativo, mientras que el secretario y el clavario -este último encargado de administrar las cuentas- estaban a las órdenes de los adelantados.

Cada aljama se regía por sus propios estatutos particulares, otorgados o ratificados por el monarca aragonés.

En teoría se buscaba que en el gobierno interno de la comunidad estuvieran representados los tres grados sociales o "manos" de la sociedad judía, pero en la práctica la oligarquía mantuvo el control de la aljama a pesar de las tendencias democratizadoras visibles ya en el siglo XIV.

Las disensiones internas por el nombramiento de cargos estuvieron a la orden del dia, obligando a los monarcas a dictar normas contra tales abusos, como hizo Juan I en diciembre de 1390 para la aljama saguntina (25), y otro tanto en 1403 la reina doña María. Menudearon las quejas ante el baile general del reino de individuos que se conside-

(24) ROMANO, David, Aljama, Aljama frente a juderia, call y sus sinónimos. Sefarad, XXXIX (1979), pág. 347-354.

(25) A.C.A. Cancilleria real. Reg. 1.898 , fol. 140 r.-141 r. 
raban postergados en sus candidaturas al puesto de adelantados, y exigían que se cumplieran las normas vigentes.

La elección se efectuaba por el procedimiento de introducir los nombres de las personas elegibles en cajas o bolsas. En la aljama de Morvedre los cargos aparecen ocupados este siglo por miembros de las familias Adzoni, Toledano, Rodrich, Bonet, Gallego... y sobre todo Façan.

En ocasiones los abusos o una mala gestión en el cargo podían llevar aparejados la pérdida del mismo a iniciativa de las autoridades reales. En 1436 el baile general pidió a los adelantados de Morvedre que relevaran del puesto de clavario a Jacob Alagian (26).

De las restantes aljamas apenas tenemos noticias. En 1424 una carta del baile general dirigida a los adelantados y clavario de la aljama les autorizaba a elegir cada año cinco consejeros que pudieran intervenir en los negocios de la aljama (27). El objetivo era democratizar la vida interna de la aljama, controlada por adelantados y clavario, y fuente de abusos en el campo impositivo y de numerosas tensiones internas.

Estos excesos de los poderosos, que no estaban dispuestos a renunciar al control del poder, se veían favorecidos por el uso y abuso que hacian del llamado "vet e alamne" (derecho de expulsión), una de las prerrogativas de los adelantados.

La documentación no es muy explícita para poder seguir las vicisitudes internas de las aljamas valencianas, cuya situación no siempre fue boyante, a pesar de la fama de ricos de que gozaron los judíos. Prueba de ello son los apuros económicos que tuvieron que soportar muchas aljamas del reino. Ello se reflejaba en el pago de los impuestos, que cuando la situación es adversa se pagan mal o no se pagan. En Morvedre, por ejemplo, los adelantados se quejaron en varias ocasiones a las autoridades reales de la pobreza de la aljama a raíz de las epidemias y solicitaron moratorias impositivas, so pena de verse despoblada la judería (28).

\section{El matrimonio y la muerte}

Del matrimonio entre los judios valencianos por estas fechas nos

(26) A.R.V. Bailia, 1148, fol. $176 \mathrm{v}$.

(27) A.R.V. Bailia, 1146, fol. 64 r.-v.

(28) A.R.V. Maestre racional, 42, fol, 311 v.-312 r. Año 1422, también en 1438 azota la peste Morvedre. 
han quedado muy pocas noticias, y en la mayoria de los casos se refieren a cuestiones de dote. De las capitulaciones matrimoniales o ketubá se conserva un documento en la catedral de Valencia de mediados del XIV.

Las dotes motivaron numerosos pleitos entre las familias judías, en los que no vamos a entrar en detalles (29).

Aunque el divorcio era aceptable desde el punto de vista legal, siempre llevaba aparejadas consideraciones de orden moral. Podemos citar el permiso dado en 1424 por el baile a Mossé Benpelig para contraer segundas nupcias tras el abandono contra su voluntad de su esposa Mira (30). Otro caso de abandono fue el de Perla, esposa del rabino de Castellón, Jucef Abenmuça, que se escapó de su domicilio y se refugió en el vecino castillo de Borriol, planteando un curioso problema jurisdiccional (31).

Dentro del mundo familiar hebreo ocupa un lugar destacado el capítulo de las herencias, en torno al cual se mueven todo tipo de intereses personales. Al margen de lo dispuesto en la propia ley mosaica, las autoridades regularon diversas facetas de los mismos. Así, Alfonso $V$ en la pragmática dada en 1419 permitía a cada judío disponer de sus bienes según su libre voluntad, regulándose los casos de morir intestado o en que hubiera cristianos participando de la herencia (32).

Era frecuente que las autoridades retuvieran o inventariaran los bienes del fallecido, ante la reclamación de un pariente o bien para evitar posibles divergencias entre los herederos. Otras veces las divergencias surgían entre los propios albaceas testamentarios a la hora de repartir o administrar la herencia.

Junto a la dote, las herencias eran una garantía -en ocasiones la única- económica para personas particularmente débiles, como los menores o las viudas, víctimas a menudo de los más fuertes, pero que también fueron defendidos por las autoridades frente a tales abusos.

A veces, el testador disponía que parte de los bienes fueran a engrosar los fondos de instituciones benéficas o religiosas, como hizo en

(29) Por ejemplo, en 1429 Mira, esposa de Mossé Pelig, de Morvedre, reclamó en la corte del baile general, que éste anotara los bienes muebles de su marido, como medio de asegurarse la posesión de su dote.

(30) A.R.V. Bailia, 1146, fol. 42 r.

(31) A.R.V. Bailia, 1155, fol. 73 v. -74 r.

(32) A.R.V. Real, 630, fol. 235 r. 
1469 Jucef Gracia, de Morvedre, que en 1469 legó 25 libras para la confección de una corona para la torah de dicha judería (33).

En cuanto a los cementerios, no hay que olvidar que para los hebreos los muertos son una parte de la comunidad y los que le dan razón de ser (34). La vida en la tierra es como un período de preparación para el más allá.

Los judíos disponían de sus propios cementerios por privilegio real alli donde habitaban, situado fuera de los muros de la localidad. El problema es determinar su ubicación, ya que no han dejado restos. El mejor conocido es el "Fossar dels juheus" de la ciudad de Valencia, situado fuera de la judería, al que se accedia por el portal d'En Esplugues. Tras el asalto de 1391 el antiguo recinto fue abandonado y se buscó uno nuevo. A mediados de 1393 los judios fueron autorizados por Juan I a trasladar los huesos de sus antepasados al nuevo recinto, $y$ el 26 de mayo de 1394 el rey autorizaba la creación del mismo (35). Sobre el solar del viejo cementerio se edificó en 1491 el convento de las dominicas de Santa Catalina de Siena.

En Castellón de la Plana fue Jaime II quien en 1326 autorizó a los judíos a que compraran un terreno para cementerio, que se situó en la confluencia de los caminos de la Terra dels Canters y de la Penyeta Roja, al norte de la localidad (36). Ese mismo año también se dio la misma concesión a los judíos de Burriana (37).

En Morvedre, Alfonso III permitió a los judíos que hicieran otro cementerio debajo del castillo, designando su emplazamiento el lugarteniente del baile de la villa. En Játiva hay noticias de un cementerio judío ya en 1268, cerca de la yesería, lindando con la muralla, que en 1321 fue cercado, aunque debería tener abierta una puerta para que las tropas pudieran refugiarse allí en caso de guerra (38).

\section{La religión como elemento aglutinante}

En la sinagoga principal, centro religioso para los judíos, la oración

(33) A.R.V. Bailia, 1154, fol. 465 r.-v.

(34) CARO BAROJA, Julio, Los judios en la Espeña moderna y contemporánea, pág. 65.

(35) A.C.A. Cancilleria real. Reg. 1.857, fol. 72 r.-v.; reg. 1.909, fol. 49 r.

(36) MAGDALENA NOM DE DEU, J. R., La aljama de judios de Castellón de la Plana en la Baja Edad Media, Castellón de la Plana, 1978.

(37) MAGDALENA NOM DE DEU, J. R., La judería de Burriana (siglos XIII-XIV), Burriana, 1978.

(38) A.C.A. Cancilleria real. Reg. 219, fol. 222 v. 
desempeñaba un papel clave, además de ser centro para la enseñanza de la ley. Solía haber una sinagoga al menos en cada localidad configurada como aljama (39). En el caso de Valencia había por lo menos tres sinagogas en la ciudad antes de 1391, si bien siempre suele aludirse a la sinagoga mayor, en la que tuvo lugar la supuesta intervención milagrosa de San Cristóbal que hizo convertirse a los judíos, convirtiéndose luego en iglesia bajo la advocación de dicho santo. Se emplazaba en el lugar más céntrico de la judería.

En 1378 el obispo de Valencia, don Jaime de Aragón, concedía licencia para que en la casa de Aarón Rubio, lindando con la muralla de la ciudad, se instalara una casa de oración, de 30 por 40 palmos de medidas. Otra concesión del mismo estilo hizo en 1379 Pedro IV a instancias de Esdra, judío valenciano.

En 1385 el obispo valenciano concedía licencia, a instancias de los judíos, para que pudieran erigir una sinagoga allí donde quisieran. No sabemos si estos nuevos centros fueron puestos en pie, pero reflejan la insuficiencia de los anteriores y el crecimiento de la judería (40).

El interior de estos edificios lo desconocemos, pero no creemos que tuvieran el carácter "monumental" de otras sinagogas peninsulares. El mobiliario lo formaban una tribuna o atril (tebá), utilizado por el orador en las lecturas sagradas; una hornacina para guardar la Torah y otros libros sagrados.

Los asistentes se sentaban en asientos fijos, que eran objeto de compra-venta entre particulares, así como de frecuentes motivos de disputas. En 1455 el baile general dispuso que fueran expertos en ley judaica los que aclararan a quién correspondía un sitio en la sinagoga de Morvedre que disputaban Mosse Façan y Soli, viuda de Abenya$\min (41)$.

La sinagoga funcionaba también como hospital y hospicio, centro de enseñanza y era el marco idóneo para la publicación de bandos y ordenanzas e incluso para el arrendamiento de los impuestos.

La sinagoga de Morvedre, según Chabret y Piles, debió estar en la calle de la Sangre Vieja, números 7 al 11, convirtiéndose tras la expulsión en Cofradía de la Sangre de Cristo. Apenas tenemos datos de la

(39) A.R.V. Real, 630 , fol. 235 y sig.

(40) HINOJOSA MONTALVO, José, Sinagogas valencianas (1383-1492). Sefarad, XXXVIII (1978), pág. 293-307.

(41) A.R.V. Bailia, 1152 , fol. 1.002 
misma en el siglo $X V$, algún que otro incidente producido en la misma, pleitos por asientos o una donación testamentaria.

Sobre la sinagoga de Burriana, un documento de 1486 nos recuerda que se construyó con ayuda de otras juderías del reino y las limosnas de los judíos de la villa, sin que sepamos la fecha (42). La cita más antigua del siglo XV es de 1448 y se refiere a una queja de los adelantados de la aljama ante las pretensiones del párroco de la villa de tener dicha sinagoga bajo su señorío y cobrar un censo anual, incluidos los atrasos (43).

A lo largo de estos años la sinagoga de Burriana fue víctima de varios intentos de expolio, consecuencia de la debilidad de su comunidad en la segunda mitad de siglo. Ya en 1465 hubo un primer intento de llevarse las torahs a la judería de Castellón por iniciativa de la reina, pero fracasó por la oposición del baile general. En 1486, y ante la desintegración y despoblamiento de la aljama, los jurados de la villa quisieron apoderarse de los ornamentos sagrados, pero el baile general dispuso su traslado y custodia a Morvedre hasta que llegaran tiempos mejores (44), lo que nunca sucedió.

La reorganización religiosa de los judíos castellonenses se produjo a principios de la centuria, y en 1400 pedian a Martín I que se les vendiera una torah de las que tenía Samuel Amaray, judío de Burriana (45). En las rentas precibidas por el monarca en 1412-14 se habla ya de «la escola e sinoga dels juheus».

Personaje destacado en la comunidad judía era el rabino. Controlaba los nacimientos, bodas, etc., intervenía en cuestiones de orden moral o judicial y era juez y guía espiritual de sus correligionarios. También desempeñaba la función de notario. Todas las juderías del reino tuvieron su propio rabino.

Las aljamas -al menos la de Morvedre así lo hacia- elegian su propio rabino, lo que no siempre resultaba fácil, al entrar en juego numerosos factores ajenos a la propia función, en particular las rivalidades religiosas o familiares, obligando a intervenir a las autoridades reales.

En cuanto a las festividades judias, las noticias que nos ha dejado la

(42) A.R.V. Bailía, 1155, fol. $166 \mathrm{r}$.

(43) A.R.V. Bailia, 1150, fol. 270 v.

(44) A.R.V. Bailia, 1155, fol. 166 r., y Bailia, 1153, fol. 620 r.

(45) A.C.A. Cancilleria real. Reg. 2.125, fol. 135 r. 
documentación cristiana son muy escasas. A veces una fiesta era utilizada como marco de referencia para el pago de un impuesto, como el que pagaban antes de 1391 los judios de Valencia en la «Pascua de beneduç», si bien lo normal era hacerlo en festividades cristianas.

La mención más detallada de estas fiestas se hace en el fuero dado contra los judíos en las Cortes de 1403, en el que se establece -entre otras cosas - que tres días antes de la Pascua del pan ácimo, la Pascua de Quincuagésima, la del Año Nuevo, la del gran ayun (Yom Kippur) y la de las Cabañuelas, todos los judíos abandonarían la ciudad de Valencia y su término (46) para que así no tuvieran ningún contacto con los conversos en fechas tan señaladas.

Sobre la religiosidad del judio valenciano no tenemos más datos que el saber que acudiria frecuentemente a la sinagoga y que respetaba la festividad del Sábado.

Quedan pocas noticias sobre las cofradias judias valencianas en el siglo XV y de ninguna conocemos los reglamentos, aunque el sentimiento comunitario del hombre medieval, al margen de su credo religioso, hace pensar en una participación masiva en las mismas.

La única noticia procede de Morvedre, del año 1402, en que la reina doña María autorizó a los adelantados de la aljama, y de acuerdo con privilegios reales perdidos en el asalto a la judería de Valencia de 1391, a establecer una cofradía para enterrar a los muertos (cabbarim), otra para asistencia de enfermos (sobreholim), otra para acompañar a los muertos hasta su sepultura (netzamita) y una cuarta para la instrucción de los niños pobres (talmotorah) (47).

De la almoina o limosna privada que tenian los judíos de Valencia ha quedado una noticia posterior a 1391, que permite afirmar la continuidad de su existencia, a tenor de la evolución de la aljama hebrea, aunque no sabemos hasta cuándo duró.

Sobre la actuación de la Inquisición medieval en el judaísmo valenciano en el siglo XV es difícil pronunciarse al no quedar más que datos aislados, referidos casi siempre a la defensa de los judíos por la Corona frente a las presiones inquisitoriales, a menudo injustificadas. Es conocida - a través de Baer- la revisión del proceso inquisitorial ordenada por el rey en favor de Mosse Suxen, de Játiva, acusado de herejía en 1390 (48). A nivel colectivo los judíos saguntinos se quejaron al rey de

(46) A.R.V. Real, 630, fol. $350 \mathrm{r}$.

(47) A.C.A. Cancillería real. Reg. 2.338, fol. 157 v.

(48) A.C.A. Cancillería real. Reg. 1.850 , fol. 40 v. 
las vejaciones a que se veían sometidos por los inquisidores y otros oficiales eclesiásticos, que los acusaban de herejía. Juan I dio una pragmática para que no se procediera contra los judíos ni sus bienes, anulando cualquier proceso instruido (49). El caso de los conversos es aparte y sobre ellos no insistiremos en este trabajo.

6. Las juderías como marco de segregación. Las carnes judías y el vestido

Los judíos han vivido tradicionalmente en sus propios barrios, donde podian desarrollar sus propias formas de vida y religión. A partir del siglo XIII el antijudaísmo de la Iglesia tratará de mantener separados por todos los medios a los judíos de los cristianos.

En Valencia ya desde los momentos inmediatos a la conquista de la ciudad los judíos tuvieron su propio barrio. La segregación espacial en juderías interesaba a todos y en primer lugar a los propios judíos por razones de seguridad; de ahí que las juderías estuvieran rodeadas de un muro o empalizada que los protegía de posibles furores antisemitas. También interesaba al monarca que los podía controlar mejor, sobre todo desde el punto de vista fiscal, a la vez que era una garantía contra posibles tensiones sociales. En el marco urbano la judería era un elemento marginal, en ocasiones refugio de delincuentes $y$, en el caso de Valencia, lugar habitual de juego en su tafurería.

Es difícil localizar en el plano de las actuales ciudades la situación que ocupaba la judería, ya que no han quedado restos, salvo Sagunto.

La judería de Castellón estaba situada en la parroquia de San Pedro, en la moderna calle de Caballeros y adydacentes (50). En 1426 el baile general, siguiendo instrucciones del monarca, dispuso que los judíos residieran en un lugar apartado e idóneo, para lo cual las autoridades municipales les designarian una calle, que no conocemos, pero que permite concluir el pequeño tamaño de la comunidad hebrea castellonense (51).

En Villarreal la juderia se situaría en el ángulo N.E. del cuadrilátero que formaba el primitivo plano de la villa (52).

(49) A.C.A. Cancillería real. Reg. 1.906 , fol. 213 v.-214 r.

(50) BALBAS CRUZ, J. A., El libro de la provincia de Castellón de la Plana, Castellón, 1892, reeditado en 1981, pág. 138.

(51) A.R.V. Bailía, 1144, fol. 477 v.

(52) DOÑATE SEBASTIÁ, J. R., y MAGdALENA NOM DE DEU, J. R., Las juderías... 
La judería de Burriana estaria junto al portal de Tortosa, incluyendo las calles de Nuestra Señora de los Desamparados y la de Santa Teresa (53), mientras que en Onda sabemos que en 1450 residian en la plaza del Arrabal, de donde pretendieron expulsarlos los jurados de la villa para trasladarlos a la morería, medida que no se produjo por la oposición del baile general.

Morvedre tuvo la judería más importante del reino tras la de la capital y es la única que ha conservado su trazado, aunque los restos conservados no guardan relación con el pasado, aunque Piles Ros todavía encontró restos arquitectónicos en alguna casa del barrio (54).

La judería de Valencia fue la más extensa del reino y mereció la atención y la descripción de los principales escritores y eruditos valencianos desde fecha lejana (Esclapes, Escolano, Orellana, Marqués de Cruilles, etc.), aunque fueron Danvila y Collado en el siglo pasado, y sobre todo Rodrigo Pertegas, los que hicieron un más detallado estudio de su perímetro, calles, viviendas, etc.

Tras el asalto de 1391 el barrio judío entró en decadencia y se convirtió en zona marginal habitada por delincuentes y prostitutas, mientras que los jurados trataban de evitar que los escasos judíos que quedaban en la ciudad y los nuevos conversos siguieran residiendo en la zona. La presión municipal tuvo éxito con el tiempo y en las Cortes de 1403 se dio un fuero por el que se prohibía a los judios habitar en las parroquias de Santo Tomás, San Andrés y San Esteban, o sea, el marco de la antigua judería. La norma se mantuvo vigente durante todo el siglo (56).

La ubicación de la judería de Játiva plantea numerosos interrogantes al no haber testimonios urbanísticos o documentales sobre ello en el siglo XV, aunque Agustín Ventura la coloca entre la muralla de la ciudad y la iglesia parroquial, la Seu (57).

En Orihuela, los judíos residían a mediados del siglo XIV en la zona que iba desde el callejón de Viudes hasta el Estudio. Por una noticia de

(53) MAGdalenA NOM DE DEU, J. R., La juderia de Burriana. Prólogo de Norberto Mesado en pág. 9-10 describe la localización de la judería.

(54) PILES ROS, L., La juderia de Sagunto. Sus restos actuales. Sefarad, VIII (1948), pág. 151-156.

(55) RODRIGO PERTEGAS, J., La juderia de Valencia. Apéndice a la obra de SANCHIS SIVERA, José, La iglesia de Santo Tomás, Valencia, 1913, pág. 254.

(56) A.R.V. Real, 630, fol. 350 r.-v.

(57) VENTURA, Agusti, Posible localitzaci6..., pág. 51-52. 
1459 sabemos que los judíos que había en la localidad residían en la calle Nueva, mezclados con los conversos, por lo que el rey les prohibió seguir residiendo allí y les dio un plazo de seis meses para abandonar dicho lugar y no regresar más (58). En adelante no sabemos qué fue de ellos.

En la vida cotidiana del judío, la alimentación ocupa un lugar destacado por sus peculiaridades que permiten distinguirlo de cristianos y musulmanes. Y la carne quizá sea el aspecto más visible, por lo que las autoridades cristianas para evitar confusiones y acentuar la segregación entre los miembros de las dos castas se reguló minuciosamente cuanto concernia al lugar que debian ocupar las carnicerias judias o, por ejemplo, la prohibición de que carniceros cristianos degollaran animales para los judíos.

Sobre la carne, al igual que con el vino, recaían sisas, que eran una importante fuente de ingresos para la aljama. La falta de contratos de arrendamiento de las carnicerias valencianas nos impide conocer su funcionamiento, aunque cabe pensar que fuera similar al de otras juderías de la Corona de Aragón, como Zaragoza.

Sabemos, por alguna noticia dispersa, que algunas aljamas tenían su propia fuente de abastecimiento de carne, y asi la judería de Morvedre estaba autorizada a tener 100 cabezas de ganado en el bovalar de la villa, cifra que en 1448 los jurados cristianos pretendieron reducir a 80 , aunque sin conseguirlo.

En cambio, las comunidades pequeñas tenían problemas de abastecimiento y algunas tenían que acudir a los carniceros cristianos, lo que motivaba fricciones con la comunidad cristiana, que consideraba impuros los alimentos judíos y se veía en inferioridad respecto al judío. Las autoridades buscaban una autoridad conciliadora, y en 1427 en Burriana se firmó una carta pactada entre los jurados y los judíos que contenía la obligación de matar carnes para los hebreos de la villa, aunque luego hubo problemas a la hora de su aplicación. Tampoco la aljama de Castellón de la Plana tuvo carnicería propia durante gran parte del siglo, con las consiguientes molestias para la comunidad al negarse los carniceros cristianos a cortarles las carnes. La situación mejoró al degollar las reses el rabino local, aunque se buscó una hora en que no hiriera la sensibilidad de los cristianos (59).

En Valencia desapareció la carnicería con la judería y como medida

(58) A.R.V. Real, 90, fol: 26 r.-v.

(59) A.R.V. Bailía, 1151, fol. 366 v. 
de presión antijudía se prohibió a los judíos que estuvieran en la ciudad (año 1403) degollar animales en la carnicería. En Játiva la carnicería judia se situaba a fines del siglo XV en el arrabal de les Barreres.

La sociedad medieval necesitaba identificar a cada uno de sus miembros, en particular aquellos que practicaban otra religión, como musulmanes o judios, para evitar su confusión con los cristianos. La doctrina de la Iglesia y su postura antijudía a partir del IV Concilio de Letrán (1215) hizo hincapié en las medidas de segregación contra los judios, siendo el vestido uno de los medios utilizados.

Ello suponia una humillación para los judios, agravada por la obligación de llevar una rueda o círculo (roda) de paño de distinto color. Esta medida fue aplicada en la Corona de Aragón ya desde el siglo XIII, aunque los judios trataron de zafarse de tan ignominiosa disposición por todos los medios, consiguiéndolo alguno de ellos a título individual.

No obstante, con el tiempo la norma se fue relajando y no se puso mucha atención en su mantenimiento. De hecho, en 1396, con los pogroms todavía recientes, los judíos saguntinos vestían de tal manera que no se les distinguía de los cristianos y conversos, por lo que Juan I dispuso que llevaran una túnica larga de color oscuro y una rueda de paño rojo sobre el pecho (60).

La postura real ante la rueda en el vestido fue variable, y si en 1393 obligaba a los judios de Valencia a llevarla, en 1394 revocaba la anterior disposición para evitar posibles violencias físicas contra los hebreos. Era una política distinta a la intolerancia que caracterizaba a las autoridades municipales. A fines del siglo XIV los judíos vestían túnicas largas de paños oscuros, capirotes grandes hasta la espalda con doble cogulla y una rueda roja.

La presión antijudía plasmada en los fueros de 1403 se reflejó también en el vestido y se volvía a insistir en la obligación de llevar una rueda roja al pecho. No obstante, la situación mejoró con la política favorable a los judios de Alfonso $V$, que en 1419 dispuso que se les dispensara de llevar dicha señal por los caminos, a fin de evitar peligros.

7. Judios, cristianos y musulmanes

El judío no era un ser que pudiera vivir aislado, encerrado en el

(60) A.C.A. Cancilleria real. Reg. 1.911 , fol. 46 r. 
estrecho marco de su judería, sin contactos con los otros grupos sociales, en nuestro caso cristianos y musulmanes. La residencia preferentemente urbana y razones de tipo profesional empujaban al acercamiento. Frente a las medidas segregacionistas propugnadas por las autoridades laicas y eclesiásticas, la realidad era bien distinta y miembros de una u otra religión convivían en la vida cotidiana, en los aspectos más íntimos como bautizos, bodas $u$ otros festejos, y no digamos en el terreno de lo lúdico, al que tan aficionado era el hombre medieval.

Judíos y cristianos se relacionaban por motivos profesionales, particularmente en el campo comercial: la compra y venta entre unos y otros estaba a la orden del día. A veces los cristianos les encargaban trabajos artesanos, como en 1432 hizo Pedro Bertos, peletero de Valencia, que entregó a Astruch Cabalmale, de Castellón, cierta ropa de piel para que se la cosiera y acabara (61). No faltaron tampoco los alquileres de viviendas de hebreos a cristianos.

Era también frecuente el nombramiento de procuradores cristianos -a menudo conversos- por parte de judios, a fin de recuperar deudas, bienes, representarlos en juicios, etc., siendo en los diez años posteriores a los pogroms de 1391 cuando mayor número de estas procuras se conservan, sobre todo de judíos de Morvedre.

Como muestra curiosa de asociación entre judío-cristiano hay que citar la que en 1473 llevaron a cabo fray Juan, ermitaño de Santa Magdalena, de Castellón, Ramón Canet, de Lucena, y Abraham Vires, rabino de la aljama de Castellón, para buscar tesoros y metales, para lo cual consiguieron del baile general la oportuna licencia (62).

Hubo también cristianos que participaron en las banderías internas de la aljama saguntina, en las que en 1433 enfrentaban a Abraham y Samuel Agi con Jaffuda Maym'o, Salamo Tarfón y diversos moros.

Pero las cosas no siempre fueron fáciles para los judíos y a nivel de comunidades las tensiones entre judíos y cristianos menudearon a lo largo del Cuatrocientos, aunque por fortuna no se volvió a verter más sangre. En Burriana, por ejemplo, en marzo de 1427, una carta de Alfonso $V$ dejaba traslucir la existencia de conspiraciones y amenazas contra los judíos de la villa por las gentes de la misma, sin que sepamos la motivación.

Otras veces era la muerte de un cristiano o cualquier otro acto

(61) A.R.V. Bailia, 1147, fol. 372 v.

(62) A.R.V. Bailia, 1155 , fol. 78 v. 
delictivo contra un miembro de esta comunidad por parte judía lo que soliviantaba a la población, como pasó en Morvedre en 1430 cuando la supuesta muerte de un cristiano por un judio armó gran revuelo en la villa (63).

Los momentos de mayor tensión se vivían en Semana Santa, al ser considerados los judíos como el pueblo deicida, lo que hacía recaer sobre ellos las iras populares, llegando a ser apedreados por dichas fechas en el siglo XIII. Las autoridades velaban por su seguridad esos días, llegándoles incluso a cobrar el llamado "dret de protecció», que en Morvedre era de 150 sueldos anuales.

Otro caso de tensión judeo-cristiana se produjo en Villarreal a finales de 1477, en el que se produjeron malos tratos contra los judíos de la villa, por lo que el baile general dispuso que se colocara la señal real en la puerta de las casas de los cuatro judíos que vivían en la localidad, a la vez que mostraba su asombro y protesta por el desinterés de las autoridades municipales en castigar a los culpables (64).

Las riñas y peleas entre miembros de las dos comunidades no fueron raras, pero pocas veces llegó a correr la sangre, y en líneas generales el índice de conflictividad parece que fue bajo.

Lo que sí que menudearon fueron los pleitos, generalmente por razones de deudas, como consecuencia de los intercambios comerciales judeo-cristianos.

En las relaciones con los musulmanes, la documentación arroja menos luz, y lo mercantil ocupa un lugar destacado. Los judios saguntinos, por ejemplo, vendían sus manufacturas -en concreto los plateros- por las morerías de la comarca. También encontramos un ejemplo de asociación judio-moro (Salamo Zalmati, de Játiva, y Acen Catim, de Bechí) para buscar tesoros y metales preciosos en los términos de la Pobla Tornesa y Benicassim (65).

Los roces entre ambas comunidades - siempre a título individualnacieron por motivaciones económicas: deudas principalmente, quejas contra la usura judiega, reclamaciones por alguna parcela de tierra, etc., procediendo la mayoría de las noticias de las comarcas del Bajo Palancia y la Plana, donde ambas comunidades tenían densa población.

(63) A.R.V. Bailia, 1147, fol. 219 v.

(64) A.R.V. Bailia, 1155, fol. 770 r.-v.

(65) A.R.V. Bailia, 1155, fol. 54 v.-55 r. 
Resulta difícil conocer con precisión las profesiones ejercidas por los judios ante la falta de referencias documentales directas. Señalar, ante todo, el alejamiento del hebreo del mundo rural valenciano y su dedicación a los sectores secundario y terciario. Ello ha llevado en ocasiones a una supervaloración de la influencia judia en la economía medieval de un país, en algún caso, como el de Valencia, sin ninguna prueba concreta (66).

Las actividades de los judíos valencianos no diferían de las del resto de los judios peninsulares: trabajos de una intensa dedicación profesional y destinados a una reducida clientela de poderosos, caso de la orfebrería o sedería, que en el siglo XV continuó en manos de los conversos. La industria textil, sastres, zapateros, etc., cubrían las actividades de la mayoría de los artesanos de las juderías.

Los más poderosos y hábiles se dedicaban al cambio y al comercio, aunque hay que hacer también una distinción entre el gran mercader, que participa en el comercio internacional -fundamentalmente el norte de África-y el pequeño marchante que tenia su propia botiga en la judería o recorría con su género las comarcas vecinas. Sólo los poderosos eran grandes prestamistas, arrendadores de impuestos o mercaderes destacados.

\section{La usura y el préstamo}

Los judíos aparecen especializados en la Edad Media en el depósito de numerario y en la actividad crediticia. Ya es sabido de sobra la mala fama y la animadversión que ello les trajo entre los cristianos. La legislación foral trató de controlar la usura judiega y se estipuló que el interés oficial de los préstamos fuera de un 20 por 100 . Lo que no impide que la usura encubierta estuviera a la orden del día.

El préstamo judío estaba muy difundido entre la sociedad valenciana, tal como se comprueba en los protocolos notariales de $1386 \mathrm{del}$

(66) Como ha realizado Angelina García en el número 2/3 de la revista Debats, publicada por la Diputación Provincial de Valencia en 1982 al afirmar que la prosperidad económica de Valencia en el siglo XV era el resultado de las cien familias conversas de la ciudad, sin aportar ningún dato concreto. Lógicamente, la persecución de la Inquisición contra los conversos produciría el hundimiento de la economía valenciana. Demasiados parecidos con hipótesis similares para Barcelona. 
notario valenciano Bartolomé de la Mata (67). Los principales clientes de los judios de Valencia eran los campesinos. Los judíos se desplazarían a los pueblos de los alrededores registrando los contratos en los notarios locales o en los de la ciudad.

Se observa que los préstamos tenían lugar preferentemente en los meses de septiembre a noviembre y también de marzo a junio, con un descenso estival. Como señala Kriegel, puede considerarse a estos préstamos como reguladores de la vida rural.

A los campesinos les siguen en importancia las gentes de la ciudad, que desempeñaban profesiones muy diversas, desde pescador a notarios, pasando por diversas ramas del textil. Se echan de menos los préstamos a las gentes pertenecientes a la capa superior de la sociedad, y la clientela de este notario se incluiría en un nivel medio, sin que falten varios mudéjares.

La clientela procedía de muy diversas localidades en un radio de unos 30 kilómetros alrededor de la ciudad de Valencia, preferentemente de la Huerta y la Ribera Baja, amén de la propia capital, que da el mayor porcentaje de deudores.

Los prestamistas operaban generalmente de forma individual, con sus propios capitales y a través del citado notario y para el año 1386 nos encontramos con un volumen de 3,2 operaciones por individuo, aunque con desigualdades marcadas entre individuo que hacía 20 operaciones y otros que sólo hacían un contrato. Superaron la decena de préstamos a través de este notario Humer Abnayub, Jucef Abnayub, Isaac Abenafia y Mossé Aliceni. Pero lo que interesa destacar es la amplia participación de los judíos en el mercado de préstamos. En 10 meses Bartolomé de la Mata atestiguó deudas a judíos por 23.610 sueldos.

Las cantidades prestadas no eran muy altas, entre unos sueldos y un centenar de florines, a un plazo de seis meses.o un año, siendo el interés legal el ya citado 20 por 100 . El prestamista corría el riesgo de la morosidad en la devolución de las deudas y era frecuente que acudiera ante el justicia civil, que procedía a embargar los bienes del acreedor.

Tras el asalto y desaparición de la judería de Valencia las deudas judiegas no quedaron canceladas y los ahora conversos trataron de que se les pagara lo debido, lo que con frecuencia fue un proceso largo

(67) A.R.V. Protocolos notariales, $n^{\circ} 2.810$

(68) KRIEGEL, M., op. cit., pág. 89. 
y lleno de dilaciones, porque los cristianos no querían responsabilizarse de viejas deudas.

Durante el siglo XV los judios siguieron practicando el préstamo, pero las noticias son fragmentarias. Todo hace pensar que fue en Morvedre donde residían los más acaudalados prestamistas, y en 1479 recoge Chabret la noticia de que los jurados de Jérica, agobiados por las deudas, tuvieron que recurrir a los préstamos de los judíos saguntinos, dejando en prenda varias piezas de orfebrería, como un plato de Santa Águeda, la cruz procesional y algunos cálices (69). Su radio de acción sería la cuenca del Palancia, la Plana castellonense y la Sierra de Eslida, donde los moros de la zona mantenían frecuentes vínculos monetarios con los judíos.

En Castellón de la Plana ejercieron de prestamistas Samuel Azarilla y varios miembros de la familia Legem, que juraron ante el justicia de la villa a no obtener dinero por medio de usura ni a cobrar más interés del legal.

Otra profesión que casi era un monopolio de los judíos era la de corredor, sobre todo los de oreja. Aunque la bula de Benedicto XIII les prohibió ejercer tal profesión, fueron autorizados nuevamente en 1419 por Alfonso V. En Castellón de la Plana este oficio estuvo controlado por miembros de la familia Legem: Jacob (1441-1448), Jafuda (14551484), aunque también lo ejercieron otros, como Jaime Quatorze, Gento Sibili, Mosse Caxo, etc. Juraban su profesión ante el justicia de la villa y los Doce Mandamientos de la Ley de cumplir honestamente con su profesión sin fraudes o engaños.

\section{Las actividades comerciales}

Es junto con el préstamo la actividad característica de los judíos y todos los estudiosos hacen hincapié en la trascendencia de tal profesión. En el caso valenciano las mejores y más completas fuentes para conocer el comercio hebreo son las que se refieren a los productos prohibidos que se exportaban desde la ciudad de Valencia, les «coses vedades". Bien entendido que se refieren exclusivamente al comercio de exportación de la capital y que en 1433 se interrumpen las series, pero a pesar de tales limitaciones podemos aproximarnos bastante bien a este tráfico.

(69) CHABRET, Antonio, Sagunto. Su historia, sus monumentos, Barcelona, 1888, vol. II, pág. 350. 


\section{EL COMERCIO DE EXPORTACIÓN}

A lo largo de esta centuria son varios los centenares de judíos que pasan por Valencia realizando sus operaciones mercantiles. Ante la pregunta de si se trata de mercaderes profesionales caben dos respuestas: por un lado, estarían aquellos que ejercen el comercio de manera ocasional, que vienen a Valencia, compran algún producto y regresan a sus lugares de origen; por otro, los judios que aparecen mencionados varias veces en la documentación e incluso en varios años, por lo que los incluiríamos en la categoría de mercaderes profesionales.

Respecto a los métodos comerciales utilizados por los judíos valencianos, apenas podemos decir nada, si bien la impresión coincide con la opinión de Kriegel de que los judíos mediterráneos no utilizaron los medios comerciales más avanzados (70). Sabemos que formaban asociaciones comerciales, compañías de estructura simple, de un par de socios o pocos más, que aportaban capital y trabajo y se repartían los beneficios. Un ejemplo es la que formaron a finales del siglo XV Jacob Toledano y Mira Çaporta en Morvedre, cuya existencia conocemos por las divergencias surgidas entre ambas partes a la hora de hacer cuentas y resolver las deudas pendientes.

En las relaciones con el norte de África estas sociedades fueron habituales, con participación de la mitad o dos tercios de la mercancía entre los judios valencianos y berberiscos.

En sus desplazamientos podían utilizar la vía terrestre, saliendo de la ciudad de Valencia, o marítima, desde su puerto o Grau. Predominan de manera neta los viajes por tierra a los marítimos, orientados a Portugal, islas Baleares y norte de África.

La cifra anual de mercaderes judíos comerciando con este tipo de productos entre 1391 y 1433 es baja comparada con el total de mercaderes cristianos y se sitúa entre el 1,5 por 100 y 2,5 por 100 para los viajes terrestres y poco más del 1 por 100 para los marítimos.

Es difícil precisar en la mayoria de los casos su procedencia, ya que el escribano sólo anotó por lo general el nombre del individuo y el apóstrofe "juheu" (judio). Para aquellos casos en que se indicó el lugar de origen se observa un predominio.total de judíos castellanos, en los que también se incluirian muchos de los que no se consignan datos, al dirigirse preferentemente a Castilla. En este reino las juderias

(70) FRIEGEL, M., op. cit., pág. 77. 
eran numerosas, algunas muy importantes, amén de que los intercambios comerciales entre Valencia y Castilla eran los más importantes entre los reinos peninsulares. Murcia, la Mancha (sobre todo Huete) y las comarcas fronterizas proporcionaban los mayores contingentes de hebreos castellanos.

A los castellanos les seguian en importancia los portugueses, que vendrían de las principales ciudades del país: Lisboa, Viana, Porto, Lagos, Évora, etc.

A pesar de la desorganización que se produjo en las aljamas del reino de Valencia a finales del siglo XIV, los judios del reino siguieron manteniendo contactos con los de la capital, sobre todo los de Morvedre, los más próximos y activos.

La mayoría de los judíos aragoneses venian de Teruel, los más próximos geográficamente. De manera aislada se documentan judíos mallorquines, navarros, catalanes, del norte de África, Malta o Sicilia.

Las mercancías extraídas por los judíos desde Valencia se dirigen hacia el reino de Castilla, aunque a mediados de la primera década del siglo XV se interrumpió el tráfico por el cierre de las fronteras entre ambos reinos, hasta 1409. Muchos de los judíos que iban hacia Murcia lo hacian por mar hasta los puertos de Guardamar o Cartagena. Para evitar peligros, en ocasiones viajaban en grupos.

El comercio con Portugal era normalmente de carácter marítimo y viajaban en las flotas portuguesas que Ilegaban al puerto de Valencia durante el primer trimestre del año.

El comercio dentro del propio reino de Valencia tenía lugar con aquellas localidades que contaban con aljama, pero los contactos comerciales con Valencia no parecen revestir gran importancia, al menos eso es lo que reflejan las fuentes. En cambio, sí que hubo una intensa actividad mercantil judía en las zonas próximas a sus lugares de residencia. En 1404 la reina doña María autorizaba a los judios de Morvedre que comerciaban con Onda a que no llevaran en dicha villa la señal distintiva, para no ser escarnecidos (71). Sabemos que también comerciaban con sus productos por la Vall de Uxó y la vecina localidad de Petres, a la que les prohibieron ir en 1473 los jurados saguntinos $y$ comerciar con los moros, pero el baile general anuló tal medida al no entrar los jurados en el terreno jurisdiccional de los judíos, competencia tan sólo del citado funcionario real (72).

(71) A.C.A. Cancillería real. Reg. 2.340 , fol. 38 r.

(72) A.R.V. Bailia, 1155 , fol. 150 v. 
Los productos exportados por los judíos se incluyen dentro del grupo de los prohibidos, es decir, materias primas y manufacturas cuya salida del reino estaba controlada por las autoridades, además de abonar un impuesto especial, el dret de treta de coses vedades. Mientras que en las extracciones por tierra se sacan pocos artículos, en los viajes por mar hay una mayor diversificación de mercancías.

Entre las materias primas destacan los minerales: hierro, cobre, acero, estaño, plomo y las fibras textiles, como el cáñamo. Los judíos sacaron gran cantidad de armas valencianas hacia Castilla y Portugal, sobre todo puñales, de los que en 1415 se llevaron 546 al reino de Murcia. También menudearon los objetos de uso doméstico, destacando los cuchillos, reflejo de la brillante industria del metal en Valencia. En objetos de mobiliario los cofres eran los que tenían mayor demanda.

Los artículos que podríamos calificar como industriales son muy variados: tijeras, dedales, etc.; otros, relacionados con el mundo agropecuario, como las cardas o cascabeles..., o, por ejemplo, las agujas, objeto de una fuerte demanda.

No faltaron tampoco los objetos de lujo y ornamentales, tanto de mobiliario como individuales: piezas de armas, vajillas, anillos, tazas, collares, dagas guarnecidas de plata, etc.

Productos, en definitiva, que se inscriben en la corriente general del comercio valenciano del siglo $\mathrm{XV}$, en el que las manufacturas ocupan un lugar cada vez más importante, frente a la tónica anterior en la que las materias primas eran la base. No olvidemos tampoco el importantísimo papel que como centro redistribuidor de productos extranjeros hacia tierras interiores desempeñaba Valencia a finales de la Edad Media.

\section{EL COMERCIO DE IMPORTACIÓN}

Las noticias sobre esta rama del comercio son dispersas e inconexas, pero esto es un problema general para todo el comercio de importación en Valencia. Se observan tres grandes rutas: la de Castilla, Portugal y norte de África.

La ruta con Castilla cabe pensar que fuera la más intensa con Valencia, si bien faltan datos que permitan comparar su valor total con otras, en concreto con la de Berbería. Los contactos se veían favorecidos por la proximidad geográfica y por el peso económico-social de los judíos castellanos. Valencia era un buen mercado para vender materias primas castellanas y llevarse manufacturas valencianas o foráneas. Ve- 
nían, sobre todo, de Murcia y su reino, trayendo seda y trigo, producto este último que también aportaban los judíos manchegos a una ciudad como Valencia, siempre deficitaria en granos. No faltaron hebreos de Trujillo, Dueñas o Medina del Campo. También importaron lanas, pieles, quesos, comino y zumaque.

Los judios portugueses, de Lisboa, Oporto, Setúbal o Viana traían a Valencia por vía marítima productos alimenticios, preferentemente pescado, fresco o adobado.

De las importaciones judías del norte de África hay datos especificados para los primeros años del siglo XV. Estos judios norteafricanos venian personalmente a Valencia o enviaban sus factores, a menudo hebreos mallorquines, ya que la isla era etapa habitual en la ruta Valencia-norte de África. Los mercaderes valencianos que importaban productos africanos eran en su mayoría conversos, como Gabriel Ballester, Pablo o Pedro Maçana, Gabriel Vives o Nicolás de Valldaura, sin que falten los musulmanes, como Caat Ripoll o Ali Benxarnit, de conocidas familias de mercaderes de la morería de Valencia. Los viajes estaban garantizados por salvoconductos reales concedidos a través del baile general del reino.

A través de Mallorca y de los puertos africanos las comunidades hebreas se inscribian en la ruta del oro, que desde Sudán y por Sijilmassa llevaba a los puertos de Tremecén, Bugía y Constantina. Los hebreos que venían a Valencia eran de Fez, Orán, Honein, Tremecén y Tenes. Viajaban preferentemente en las galeras venecianas y naves genovesas, mallorquinas y valencianas que cubrian la ruta entre ambas vertientes del Mediterráneo.

El viaje estaba lleno de riesgos por causa de piratas y corsarios, como les sucedió en 1438 a varios judíos saguntinos que habian embarcado en Alicante en el ballenero de Miguel Bonet rumbo a Berbería. Arrastrados por la corriente hacia aguas de Málaga, fueron capturados por una embarcación armada de Cádiz que apresó a los judíos y sus bienes, siendo vendidos como cautivos en Castilla. Ello motivó la protesta de los jurados de Valencia ante el rey de Castilla y la petición de libertad para personas y bienes (73).

La participación de judios y mercaderes valencianos en este comercio era de dos tercios por parte del que recibía la mercancía en Valencia y un tercio el judíc norteafricano, aunque también podían participar a medias.

(73) A.M.V., Lletres misives, 13-19, sin fol., 12 de agosto 1438. 
La gama de productos importados era bastante amplia, desde las especias al metal amonedado, pasando por el trigo, dátiles, cera, cueros, lanas, plumas de avestruz, harina, grana, algodón, perfumes, etc.

El impuesto satisfecho por este tráfico era el "vinte o dret de mig delme", en virtud del salvoconducto que les concedía el rey; cuando se trataba de oro, plata y piedras preciosas, pagaban la mitad "ço es 10 quarante», con lo que se favorecía la llegada de los mismos.

\section{El comercio al detalle}

Lo llevaban a cabo de forma permanente en tiendas al efecto, que solian estar en las juderías o fuera del recinto, tal como indica la pragmática de Alfonso $V$ de 1419, que les autorizaba a "tener tienda entre christianos de sol a sol», aunque regresando luego a sus domicilios. Las dimensiones de estas tiendas serían muy reducidas, poco más que un depósito de mercancías o minúsculo obrador, tal como todavía podemos ver en las medinas de ciudades marroquíes, como Fez o Marraquex.

La religión no era un impedimento para estos contactos comerciales y los funcionarios municipales vigilaban que la seriedad y la honradez presidieran dichas transacciones, quedando como último recurso para arbitrar cualquier diferencia que surgiera el baile general.

\section{Las actividades de transformación}

A ellas se dedicaban la mayor parte de la poblaeión hebrea, y basta hojear las pragmáticas o bulas de la época para comprenderlo. Su habilidad profesional destacó en algunos campos particulares, como la industria sedera, con importantísimas cotas de participación judía en la ciudad de Valencia, continuada después por los conversos.

La platería fue también otra de las especialidades judías. En Valencia el número de judíos plateros antes de 1391 era muy elevado y muchos siguieron ejerciendo como tales tras su conversión al cristianismo. Varios obradores del zoco judío de la capital estaban en manos de plateros. En el siglo XV fue Morvedre la que tuvo los judios plateros más importantes, destacando Vidal Astori en el último cuarto de siglo. En 1467 obraba una silla de montar para la reina doña Juana, que al morir ésta fue destinada a su hijo don Fernando. Su alta cualificación personal merece que se le califique como "argenter de la magestat del senyor rey», es decir, platero real (1489). 
Estos judíos plateros saguntinos, que vendian sus propias manufacturas por las comarcas vecinas, en particular a los mudéjares, redactaron en 1465 sus propias ordenanzas para uso interno - aunque desconocemos su contenido-, pero fueron suprimidas de manera fulminante por el baile general al haber sido confeccionadas sin su permiso, castigándose con 50 florines de multa a los firmantes de dichos capitulos, y con 100 a los que hubieran usado de ellas (74).

Otra actividad minoritaria en la que destacaron los judios valencianos, y luego los conversos, fue la de encuadernadores de libros.

Al margen de la industria de lujo, la mayoría de la población se dedicaba a toda una amplia gama de oficios similares a los de los cristianos, entre los que merecen citarse los textiles, zapateros, sastres, etc. Aunque se ha hecho hincapié en el importante papel que los judios tenían en la industria textil, en el caso valenciano la documentación no parece confirmar tal situación. En Castellón, por ejemplo, se documentan dos cardadores de lana y un judío tintorero, y como nota llamativa anotemos la presencia en Burrina de varios judíos sardos peleteros en 1431.

Muy numerosos fueron los sastres, profesión típicamente judía donde las haya. Los hubo en todas las juderías. En Onda, por ejemplo, sastres y plateros eran las actividades básicas de los hebreos. En Villarreal los sastres judios trabajaron con frecuencia para el Consell de la villa. La calidad de su trabajo hacía que se les encargaran trabajos desde otras localidades, amén de suscitar recelos entre sus colegas cristianos, que por todos los medios presionaban a las autoridades locales para que se les limitara su actividad. En Valencia en 1477 y 1484 había judios que clandestinamente ejercían de sastres, por lo que fueron multados por el Maestre Racional. Sastre destacado fue Mosse Abuzmael, de Morvedre, que en 1459 era sastre de la reina.

\section{Profesiones liberales}

La única que se documenta esta centuria es la de médico. García Ballester ha resaltado la trascendencia que los sucesos de 1391 tuvieron para la medicina tradicional judeo-árabe en Valencia (75), en el

(74) A.R.V. Bailia 1153, fol. 662 v.

(75) GARCIA BALLESTER, Luis, Arabismo y escolástico en la medicina valenciana bajomedieval, III Congreso Nacional de Historia de la Medicina (Valencia, 1969), pág. 15-30. 
sentido de una decadencia, a lo que se añadirían las conversiones y el tránsito desde finales del siglo XIV de la tradición medieval judeo-árabe a la renacentista italiana. En Burriana, el médico judio Vidal Gracia, posiblemente oriundo de Barcelona y favorecido en 1390 con privilegios reales, se convirtió al cristianismo y como Gracia de Ribes emigró en 1393 a Foix con todos sus parientes, un total de dieciséis personas (76).

Aunque la medicina judía valenciana bajomedieval no tuviera la brillantez de otros reinos peninsulares, ello no obsta para que hubiera individualidades destacadas, como los médicos saguntinos rabí Alfangi y rabí Samuel, que en 1466 fueron llamados por el rey de Aragón para que curaran a su hijo don Alfonso de Aragón, aquejado de enfermedad del riñón (77).

\section{La propiedad judía}

Hablar de la propiedad judía resulta difícil por la parquedad de las fuentes, salvo algunos años en Castellón de la Plana. No hay que olvidar, por otra parte, la profunda conmoción que en este terreno produjeron los pogroms de 1391, que hizo que muchos judíos vieran sus propiedades saqueadas, destruidas, sin posibilidades de recuperación. Los mismos conversos tuvieron graves problemas a la hora de recuperar deudas, por ejemplo.

En el marco urbano la propiedad básica era la casa (alberch, hospitium, palatium, casa, etc.), donde residia el individuo, tratándose de viviendas propias o alquiladas. A ella se añadian corrales, bodega, huerto, todo ello dentro del marco de la judería, alli donde la había. En cuanto a tiendas $u$ obradores, sabemos que hubo zocos judaicos en Valencia y Játiva.

La propiedad urbana de Castellón de la Plana ha sido estudiada por Magdalena Nom de Deu. Ya desde principios del siglo XV los judíos, aun sin estar organizados en aljama, poseían bienes muebles por los que pagaban un censo anual al monarca. A partir de 1427 se lanzan a la adquisición de bienes muebles y propiedades rústicas, consignadas en los Libres de values de peita desde 1432, siendo estos años treinta los que ofrecen un valor fiscal más alto, con las casas como tipo de propiedad más extendida, seguidas por corrales y bodegas en muchisima menor proporción.

(76) MAGDALENA NOM DE DEU, J. R., La aljama judia de Burriana, pág. 38.

(77) A.R.V. Bailia, 1153, fol. 814 v. -815 r. 
En el ámbito rural, la propiedad judía, dispersa por el término municipal de la localidad donde residian, parece que tuvo poca importancia, tanto a nivel regnícola como municipal. Viñedo y olivar ocupaban preferentemente estas tierras, destinándose la producción a satisfacer las propias necesidades de consumo. Su existencia nos es conocida a través de los litigios o las transacciones comerciales a que dieron lugar.

En la propiedad rural de Castellón hay un predominio absoluto de los viñedos sobre cualquier otro cultivo. Se compran viñas a cristianos al compás que crece la aljama y en 1468 la extensión de tierras judías se ha cuadruplicado con relación a 1371 , en lo que hace a viñedos, en tanto que lo que se califica genéricamente como "tierras" se mantienen estacionarias o han disminuido. La extensión de los viñedos oscilaba entre 4 y 6 hanegadas, entremezcladas con otras parcelas de cristianos y el número de propietarios nunca superó los ocho.

En las «tierras»-que podían ser regadas- la extensión media por parcela era de 4,28 hanegadas. A partir de 1485 se produce un hundimiento en las propiedades rústicas de los judíos de Castellón, paralelo al de la aljama. Había también campos de algarrobos, con 63 hanegadas, y de eriales.

En cuanto a la ganadería, sabemos que en 1448 los judíos de Morvedre disponian de ganado propio, que pastaba en el bovalar de la villa, con un total de 100 cabezas. Los jurados pretendieron disminuir a 80 el número de las mismas, motivando las protestas de la aljama ante el baile (79). Cabe pensar que en Burriana, Játiva o Castellón tuvieran rebaños similares para satisfacer el consumo interno de la comunidad.

\section{III.--LAS JUDERÍAS DEL REINO DE VALENCIA EN EL SIGLO XV}

\section{La aljama de Castellón de la Plana}

Su desarrollo ha sido analizado por Magdalena Nom de Deu, y aquí, como en otras juderías del reino, los sucesos de 1391 representaron un corte de raiz con la etapa anterior. La aljama desapareció, aunque siguieron viviendo judíos en la villa a título meramente personal. En 1400 eran tan sólo cinco casas de hebreos las que habia. Martín I, dispuesto

(78) MAGDALENA NOM DE DEU, J. R., Nuevos datos sobre la aljama judia de Castellón de la Plana, Anuario de Filología, 4 (Barcelona, 1978), pág. 199-246.

(79) A.R.V. Bailía, 1150, fol. 286 r. 
a incrementar las rentas reales, dio una pragmática por la que todos aquellos judíos que acudieran a residir a Castellón serían francos durante 10 años de todo impuesto, no podrían ser arrestados por deudas o contratos y al mismo tiempo les autorizaba a reunirse y elegir entre ellos los adelantados que creyeran oportuno, pudiendo dictar odenanzas o taqanot (80).

Puede decirse que era el acta fundacional de la segunda etapa de la judería castellonense. Una nueva pragmática de ese mismo año autorizaba a los judios a imponer sisas sobre el pan, vino, carnes y otros alimentos (81).

El antijudaísmo latente en la sociedad cristiana en tiempos de Fernando I y Benedicto XIII se reflejó en Castellón en el acuerdo de señalarles un lugar para que vivieran apartados de los cristianos (mayo de 1416). El párroco de Santa María era el animador de esta iniciativa, en tanto que los jurados se excusaban diciendo que ya habían dispuesto su traslado al callejón de Monlober (82).

Estas medidas no pasaron del terreno de las intenciones y con el nuevo rey, Alfonso $\mathrm{V}$, se abandonó la política antijudía y en 1421 todavía vivían dispersos por la villa. Ya en 1412 aparecian constituidos como aljama y tenían su sinagoga.

El problema de buscarles una residencia definitiva, segregados de los cristianos, seguía latente durante la década de los años veinte, hasta que en 1427 se solucionó definitivamente trasladándose los judios al nuevo recinto de la judería.

La judería de Castellón entró en un proceso de crecimiento, posiblemente con judios procedentes de Morvedre, a donde se habrian refugiado en los momentos de peligro en 1391. A mediados de siglo hubo momentos difíciles de convivencia con los cristianos, que se negaban a venderles carne (1452). Esta animadversión crecía en los dias de Semana Santa y en 1473 el justicia de la villa habia dado orden de apedrear a los judios en esas fechas por haberse negado a satisfacer el tributo de protección que pagaban anualmente. A fines de siglo, en vísperas de la expulsión, la judería castellonense estaba en franca decadencia.

(80) A.C.A. Cancillería real. Reg. 2.193, fol. 134 v.-135 r.

(81) A.C.A. Cancillería real, Reg. 2.193, fol. 135 r.-v.

(82) MAGDALENA NOM DE DEU, J. R., Nuevos datos, pág. 209. 
Los judíos de Burriana se convirtieron después del asalto a la judería, desapareciendo ésta como entidad jurídica y religiosa. En 1395 -posiblemente - Juan I intentó rehacer la judería de Burriana autorizando a 10 judíos pobres de Morvedre a instalarse en la localidad. Poco después, ese mismo año, les concede los mismos privilegios que tuvieron sus antecesores y el 20 de octubre concedía la judería de Burriana a la reina, con todas sus pechas, impuestos, el mero y mixto imperio y la jurisdicción civil y criminal (83).

Sin embargo, el renacer definitivo vino de la mano de Martín I, que en 1399 concedía numerosos privilegios, amén de los que tenían anteriormente, a cuantos acudieran a poblar la judería de Burriana. El perímetro de la judería sería el mismo que tenía antes y los cristianos que tenían alli casas debian abandonarlas, abonándoles las autoridades la indemnización correspondiente. Los judíos tendrían también una sinagoga y todo el recinto se cerraría por un muro.

El éxito acompañó la empresa y en 1401 el rey les autorizaba a elegir anualmente a dos judíos como adelantados. La aljama comenzaba su nueva singladura histórica, aunque resulta difícil seguirla con precisión en la documentación. La regularidad se alcanzó, igual que en otras comunidades, en los años veinte y desde entonces aumentan las noticias. Se entra en una etpa de crecimiento y prosperidad, que alcanza hasta la década de los setenta, aunque el proceso de decadencia se había iniciado desde 1456 con la emigración de muchos judios de Burriana hacia la cercana Morvedre, sin que sepamos las causas de ello, aunque quizá fueran razones de tipo económico.

En adelante, las menciones sobre la judería de Burriana disminuyen y menudean los pleitos con judíos de la villa que habían cambiado de domicilio y se negaban a satisfacer los impuestos de su antigua residencia. Sobre la cifra de población judía en Burriana, Norberto Mesado, calculando el perímetro de la judería, da un total de 45 fuegos, que aplicando un coeficiente 3 sumarían 135 individuos (84).

\section{Otras comunidades castellonenses}

Había judíos en Onda, aunque no estaban organizados como aljama

(83) A.R.V., Maestre racional, 9.564, fol. 135 v.-136 r.

(84) MESADO, Norberto. Prólogo a la obra de MAGDALENA NOM DE DEU, J. R., La juderia de Burriana, pág. 10. 
y a mediados de siglo, en 1450 , sabemos que residian en el arrabal de la villa, donde desempeñaban las profesiones de sastres y plateros.

En Villarreal cabe pensar que no hubo matanzas en 1391 y es posible que se convirtieran algunos judíos. De todo ello no hay datos concretos. No obstante, a principios del siglo XV se detecta la presencia de judíos en la villa, a título aislado. Posiblemente su evolución fuera similar a la de las vecinas aljamas de Castellón y Burriana, creciendo paulatinamente en estos años. En 1477 había cuatro casas de judios en la villa y en este año se produjeron una serie de tensiones entre cristianos y judíos, reflejada en el mal trato hacia éstos, con el consentimiento implícito de las autoridades locales, lo que motivó la protesta ante el baile general, que ordenó se colocara la señal real a la puerta de sus casas como protección (85).

En 1492 Doñate Sebastiá sólo recoge la presencia de un judío en Villarreal.

La presencia judía en la villa de Segorbe es muy mal conocida. En realidad apenas si sabemos que en ella residian algunos hebreos en la segunda década del XV, en total ocho fuegos para 1421, entre 28 y 40 posibles personas, según el coeficiente que apliquemos $(3,5 \circ 5)$. No eran más que el 1,16 por 100 de la población.

También en la cercana Jérica, en el Alto Palancia, hubo una pequeña comunidad judia, cuyas únicas huellas se detectan en el impuesto de la pecha de 1422,1423, 1424 y 1425, oscilando el número de hogares judíos entre 12 y 15 . Nada más sabemos de su trayectoria histórica.

\section{La juderia de Morvedre}

Fue la más importante del reino, la cabeza del judaísmo valenciano a fines de la Edad Media. En los años siguientes a 1391, a pesar de haberse salvado de la destrucción gracias a la protección de las autoridades, sus habitantes atravesaron momentos difíciles, en los que la desorganización y la crisis económico-social fueron las notas predominantes. Los judios saguntinos tuvieron que abandonar sus casas ante el temor de violencias físicas, sus hogares y talleres, correr con los elevados gastos de vigilancia, a lo que se sumó la presión de los inquisidores contra personas y bienes y la peste con sus mortales secuelas.

(85) A.R.V. Bailia, 1155 , fol. 770 r.-v. 
Reflejo de esta crisis fue la dificultad para encontrar gentes capaces de desempeñar los cargos de la aljama, lo que llevó a la intervención real el 18 de julio de 1392, ordenando al baile general que recensara a los judíos capaces de desempeñar cargos. El 1 de diciembre de 1391 el rey había ordenado que cada año se eligieran 16 personas para regir la aljama: dos adelantados, un adjunto, un clavario y 12 consejeros (86).

Los años 1392 y 1394 son los intentos de la monarquía por poner en pie la aljama saguntina, para lo que se dictaron diversas pragmáticas favoreciendo a los judíos: perdón general de cualquier delito a sus moradores, protección para todos los judios de la villa; autorización a realizar sus testamentos $u$ otros contratos con el notario que quisieran, rebajas en las contribuciones, autorización en 1394 para imponer sisas sobre carne, pan, vino y otros alimentos; suspensión de investigaciones en posibles delitos sobre usura, etc.

Esta política proteccionista fue mantenida por los reyes de la nueva dinastía, y en 1418 Alfonso $V$, a causa de la peste y la disminución de la población judía, permitió al Maestre Racional subvencionar a la aljama de Morvedre. Al mismo tiempo les dio un salvoconducto general para poder ir por todos sus reinos.

Aunque hubo otros momentos difíciles -por ejemplo, en 1438 la población habia disminuido mucho por anteriores epidemias-, la aljama de Morvedre entró en un proceso de crecimiento, que en parte fue a costa de las aljamas vecinas, como fue el caso de Burriana, y en 1492 cuando se produjo la expulsión era la más poblada del reino, con 700 personas.

\section{La judería de Valencia}

El 9 de julio de 1391 fue para la judería valenciana el final de un proceso histórico iniciado en tiempos de Jaime I. Se produjo la desintegración de la aljama y del judaismo de la capital. Pero Juan I no estaba dispuesto a ver menguado el patrimonio real, por lo que pronto tomó una serie de medidas encaminadas a devolver la vida a las juderías de Barcelona o Valencia, entre otras. Como paso previo nombró a micer Domingo Mascó, doctor en leyes, como su administrador de la judería y de los bienes particulares y comunales de la misma.

Pero las medidas concretas tardaron tiempo en ponerse en práctica y hasta finales de 1392 no dio un decreto por el que se creaba la nueva

(86) A.C.A. Cancillería real. Reg. 1.852 , fol. 149 r. 
aljama de Valencia (87), especificándose el nuevo recinto de la misma. Para entonces, la sinagoga mayor había sido convertida en templo cristiano dedicado a San Cristóbal, luego centro de devoción y convergencia de los conversos. El recuerdo de la vieja judería se mantuvo durante algunos años en la toponimia urbana, pero no resistió el paso del tiempo, y hoy no subsiste ningún vestigio de ello en Valencia.

Los judíos que quedaron en Valencia siguieron residiendo al principio en la judería mezclados con cristianos nuevos, y el 19 de agosto de 1391 eran todavía unos 200. Pero las autoridades municipales no veían con buenos ojos esta situación, que suponía el riesgo de nuevas alteraciones sociales, $y$ todas sus medidas futuras se encaminarian a separar a los judios de los conversos. Para ello se les condujo primero hasta el castillo de Morvedre, donde estuvieron hasta que la situación se tranquilizó, y muchos se quedarían en aquella judería.

En mayo de 1393 el rey trató de que 60 familias de judios aragoneses se asentaran en Barcelona y Valencia, pero el proyecto fracasó. En 1396 los jurados solicitaban al rey que expulsara a los pocos judíos que aún quedaban en la judería y diera un privilegio por el que nunca hubiera judíos en la ciudad. Esta presión municipal sobre la corona se repitió en años sucesivos hasta que en 1403 en las Cortes y en los Furs aprobados en las mismas se limitaba la presencia espacial y temporal de los judios en Valencia.

En adelante la presencia de judíos en Valencia será muy reducida, casi esporádica, y con frecuencia eran judíos de otras procedencias que venian a Valencia a comerciar o por negocios.

\section{La juderia de Játiva}

Parece que tras el asalto del 10 de julio la aljama de Játiva desapareció, y aun cuando en un documento de marzo de 1393 se habla de la "aliama noviter facta", queda por dilucidar si la nueva aljama existió realmente o sólo fue una creación sobre el papel. Posiblemente todo quedara en proyecto, ya que hasta 1453 no encontramos referencias a judíos setabenses, y no puede hablarse de falta de fuentes. Abona esta hipótesis en que en dicho documento se habla de los «juheus qui son aci venguts novament». En 1461 se menciona ya la judería de la ciudad de Játiva.

Los judíos setabenses destacaron por su intensa actividad comer-

(87) A.C.A. Cancillería real. Reg. 1.905, fol. 89 v.-91 r. 
cial, tanto con el propio reino como con el exterior, particularmente hacia el norte de África y Granada.

\section{Las juderias del Sur del reino}

Son las que ofrecen una trayectoria más difícil de seguir. En Alcoy los pocos judíos que hubiera debieron convertirse, y otro tanto acaeció en Alicante. En adelante, si aparece algún hebreo será aisladamente, como un tal Isaac, que en 1426 tenía arrendado el derecho de aduana de la villa (88). También aparece algún judio en 1491 en Aspe, y en Elche desaparecieron los judíos en 1391, y en 1402 los bienes de la sinagoga fueron dados al Consell de la villa y con lo que se recaudó se repararon los muros.

En Orihuela se produjo la conversión de los judios, y hacia ellos se dirigiría el odio de la población cristiana en diferentes momentos del siglo XV, sobre todo en 1459 a raíz del asesinato de un cristiano, Juan Gómez, por Alfonso Alulayes. La celeridad de las autoridades logró atajar el levantamiento contra los conversos, pero a los judíos que residían en la villa -ignoramos su número-, junto a los conversos, en la calle Nueva, se les obligó a cambiar de residencia. Parece que los judios oriolanos en el siglo XV, que serían muy pocos, nollegaron a formar una nueva aljama.

\section{EPILOGO}

El 31 de marzo de 1492 Fernando e Isabel, los Reyes Católicos, firmaron el edicto decretando la salida de las coronas de Castilla y Aragón de todos los judíos, dándoles de plazo hasta el 31 de julio. Los puertos mediterráneos fueron utilizados como punto de embarque para numerosos judíos de los reinos de Valencia, Aragón y castellanos, destacando entre éstos la célebre familia de los Abrabanel, Isaq, Yosef y Jacob.

A través de los contratos de embarque localizados sabemos que por los puertos valencianos salieron cerca de 10.000 judíos, cifra importante dentro del conjunto total de los expulsados. Por el puerto de Morvedre salieron judios de Zaragoza, Calatayud, Huesa, Epila, Daroca, Ariza, Albarracín, El Cuervo, Belchite, además de los de Játiva (248 personas), Castellón y Morvedre (700 individuos). El día 1 de agosto de 1492 habían dejado de haber oficialmente judíos en suelo valenciano. Se cerraba una etapa histórica iniciada también trágicamente hacía un siglo, en julio de 1391.

(88) A.R.V. Real, 36, fol. 45 v. 